\title{
Androgen Receptor Staining Method
}

National Cancer Institute

\section{Source}

National Cancer Institute. Androgen Receptor Staining Method. NCI Thesaurus. Code C122861.

An immunohistochemical technique used to detect the presence of androgen receptor in a tissue sample. 